\title{
Knowledge and Adoption Level of Thompson Seedless Grape Growers of Bijapur District of Karnataka, India
}

\author{
Dasharath Dodamani $^{1 *}$, G.R. Pennobaliswamy ${ }^{2}$, S. Mahantesh ${ }^{3}$ and P. Gajanand ${ }^{1}$ \\ ${ }^{1}$ Division of Dairy Extension, ICAR-NDRI, Karnal, Haryana - 132001, India \\ ${ }^{2}$ Department of Agril. Extension, UAS, GKVK, Bangalore - 560065, Karnataka, India \\ ${ }^{3}$ Directorate of Mushroom Research, Solan - 173213, Himachal Pradesh, India \\ *Corresponding author
}

\begin{abstract}
A B S T R A C T
Keywords

Knowledge,

Adoption, Thomson seedless grape

Article Info

Accepted:

16 December 2017

Available Online:

10 January 2018

A study on knowledge and adoption of recommended cultivation practices among Thompson seedless grape growers in Bijapur district of Karnataka was carried out during 2013-14.Data was collected from randomly selected sample of 120 Thompson seedless grape growers by pre tested interview schedule method. The results revealed that majority $(62.50 \%)$ of grape growers had high level knowledge about recommended cultivation practices of grape. Cent per cent of growers had correct knowledge about recommended variety, soil, rootstock, training, irrigation and management of Thrips, Downey mildew and anthracnose. Majority of growers had incorrect knowledge about fertilizer application at winter $(70.00 \%)$ and summer $(73.33 \%)$ seasons, grafting method $(66.66 \%)$ and cycocyl application $(46.66 \%)$. Over four fifth $(86.66 \%)$ of growers belonged to high level of adoption category. Cent per cent of growers adopted recommended soil, variety, trench size, rootstock, grafting time, training, pruning and irrigation method.
\end{abstract}

\section{Introduction}

Grape (Vitis vinifera L.) is one of the most commercially important fruit crop of the world and is fairly good source of minerals like calcium, phosphorous, iron and vitamins like $\mathrm{B}_{1}$ and $\mathrm{B}_{2}$. Its juice is mild, laxative and acts as stimulant for kidneys. The area under grapes in India is 111.4 thousand hectares' with an annual production of 1,234.9 thousand tonnes and productivity of 11.1 tons/ha in 2011-12. Productivity of India is highest among the grape growing countries of the world. Grapes are cultivated to a large extent in the states like Maharashtra, Karnataka, Andhra Pradesh and Tamil Nadu. India is the $5^{\text {th }}$ largest producer of grapes appropriating 2.8 per cent of the global production (APEDA. 2012).In India, Karnataka ranks second in grape cultivation with an area of 18.1 thousand hectares' and production of 330.3 Million tonnes, with a productivity of 18.3 $\mathrm{mt} /$ ha.in the 2012. The crop is grown in 18 districts out of 30 districts of the state. Bijapur district covers the largest area of harvest of 7529 ha for grape in the state which makes a share of 56.25 per cent. After Indi (1696 ha), Basavana Bagewadi (145 ha), Sindagi (136ha) 
and Muddebihal (26 ha) are the other important grape growing taluks in districts. Farmers facing many problems like nonavailability of planting material, crop suffers from severe insects and diseases problems, non-availability and high cost of plant protection chemicals, shortage of irrigation water, lack of processing units and lack of marketing facilities etc. have contributed production constraints of grape growers in the study area. It was therefore, keeping this in view, investigation was designed with the following specific objectives

To ascertain knowledge level of grape growers on recommended cultivation practices of grape.

To know the extent of adoption of recommended production practices by grape growers.

\section{Materials and Methods}

BIJAPUR district falls in north western part of Karnataka.The district is surrounded by Gulbarga, Raichur, Bagalkot, Belgaum, and Solapur district of Maharashtra state. Among five taluks of Bijapur district, Bijapur taluk had the maximum area under grape cultivation (7529 ha) followed by Indi (696 ha), Bagewadi (145 ha), Sindagi (136 ha) and Muddebihal (26 ha). Out of five taluks only Bijapur and Indi taluks were selected for the data collection in proportion to the highest area under grape cultivation. Based on highest area under grape cultivation, two village panchayats were selected from each taluk and two villages from each village panchayat were selected. Fifteen farmers were selected from each village making a total sample size of 120 for the study. Data was collected from randomly selected sample of 120 Thompson seedless grape growers by pre tested interview schedule method.

\section{Results and Discussion}

Knowledge level of the grape growers regarding specific recommended practices of grape cultivation

From Table 1, it can be inferred that cent per cent of the grape growers had correct knowledge about recommended varieties, suitable soil, selection of rootstock, training method and irrigation method of grape and management of Thrips, Downey mildew and anthracnose. 99.66 per cent of them have correct knowledge about pruning time $(B \& F)$, GA application stage and its recommendation $500 \mathrm{ppm}$ and with respect to chemical fertilizers it is only 26.66 per cent of them possess correct knowledge and 88 per cent of them have incorrect knowledge. More than three fourth of the grape growers had correct knowledge with respect to spacing, material used for filling the trenches, FYM quantities, buds retained during both summer and winter pruning, major pests and diseases like powdery mildew. 70 per cent of respondents had correct knowledge with respect to size of the trench, time of rootstock grafting. Nearly 50 per cent of responds had correct knowledge about the Cycocyl application and its concentration, mealy bug management, marketing of grape.

More than half per cent of respondents had possessed incorrect knowledge with regard to method of rootstock grafting. The reason to use recommended variety may be due to the fact that only recommended varieties were being promoted for cultivation and nonexistence of local varieties in grape. Correct knowledge about suitable soil, spacing, opening of trenches, filling material used in trenches and irrigation method can be explained by simplicity of these practices and easy to remember the information obtained from different media. Also there was a considerable percentage of consultation with 
various informal sources like friends, relatives and neighbours by the respondents. In turn, these sources might have passed on the information to other growers. The tendency of farmers was that they prefer to contact successful farmers and try to know as much as possible. Possession of correct knowledge regarding propagation practices, gibberlic acid and cycocyl application and control of various pests and diseases of grape is due to the fact that these grape cultivation practices are similar to that of grape cultivation practices.

And almost all the respondents had experience of grape cultivation. Grape requires special care and rigid following of certain practices this might have forced them to gain appropriate knowledge about all these training method recommended by scientists. The various recommended training methods were demonstrated by almost all the orchards to their respective contracted farmers and hence more than eighty per cent of the grape growers possessed correct knowledge about this practice.

The data in Table 2 revealed that 16.67 per cent of the grape growers belonged to low level of knowledge about recommended practices of grape cultivation with a mean score of 24.16. Whereas, 20.83 and 62.50 per cent of the grape growers belonged to medium and high knowledge levels, respectively.

Grape cultivation requires awareness of specific cultivation practices. Grape is sensitive crop, it has to be cultivated systematically then only one can get profit.

Grape growers were self-motivated to learn more about rape production technology by formal and non-formal information sources available in the study area, extension participation of grape growers, educational activities organized by Department of Horticulture, KVK, grape growers association and paid extension services, might have influenced the overall knowledge level of grape growers regularly. Similar findings were reported by Sainath (1982) and Siddaraju (1992) on grape crops in Bangalore district.

\section{Adoption level of specific Thompson seedless grape cultivation practices by grape growers}

The results presented in Table 3 revealed that cent per cent of the grape growers adopted right type of soil, variety, size of trenches, rootstock, accurate time of rootstock grafting, method of training, method of irrigation, pruning time, whereas 93.33 per cent of respondents had maintained buds at summer pruning and 76.66 per cent were maintained at winter pruning. Large majority of $(86.66 \%)$ the grape growers were followed recommended spacing and only 33.33 per cent of respondents had adopted wedge method of rootstock grafting.

Cent per cent per cent of the grape growers had adopted the practices like suitable soil type, variety, opening of trenches, Establishment of orchard is an important operation which involves selection of proper site and opening of trenches.

This is also an important decision making activity for future operations. The grape growers normally approach fellow grape growers to decide trench size. Adoption of recommended root stock, grafting method and grafting time is due to the fact that these grape cultivation practices are similar to that of grape cultivation practices. And almost all the respondents had experience of grape cultivation, while majority of them still cultivating grapes. Further, it was seen that over cent per cent of the grape growers had adopted dog ridge as root stock which are having an advantage of drought resistance, salt tolerance and nematode tolerance. 
Table.1 Knowledge level of the Thompson seedless grape growers regarding specific recommended practices of grape cultivation $(n=120)$

\begin{tabular}{|c|c|c|c|c|c|}
\hline \multirow{3}{*}{$\begin{array}{l}\text { Sl. } \\
\text { No. }\end{array}$} & \multirow[t]{3}{*}{ Recommended practices } & \multicolumn{4}{|c|}{ Knowledge level } \\
\hline & & \multicolumn{2}{|c|}{ Correct knowledge } & \multicolumn{2}{|c|}{$\begin{array}{l}\text { Incorrect } \\
\text { knowledge }\end{array}$} \\
\hline & & Frequency & $\%$ & Frequency & $\%$ \\
\hline 1 & $\begin{array}{l}\text { Soil type } \\
\text { Well drained sandv loam }\end{array}$ & 120 & 100 & 0 & 0 \\
\hline 2 & $\begin{array}{l}\text { Recommended grape varieties } \\
\text { Thompson seedless }\end{array}$ & 120 & 100 & 0 & 0 \\
\hline 3 & $\begin{array}{l}\text { Spacing } \\
3 \mathrm{~m} \times 3 \mathrm{~m} \\
\mathbf{3 . 6} \mathrm{m} \times \mathbf{3 . 6} \mathrm{m}\end{array}$ & 104 & 86.66 & 16 & 13.33 \\
\hline 4 & $\begin{array}{l}\text { Trench/pit size } \\
1-2 \text { cu.ft }\end{array}$ & 84 & 70 & 36 & 30 \\
\hline 5 & $\begin{array}{l}\text { Material used for filling trenches } \\
\text { FYM and Super phosphate }\end{array}$ & 96 & 80 & 24 & 20 \\
\hline 6 & $\begin{array}{l}\text { Quantity of filling material } \\
\text { FYM - } 20 \text { T/acre } \\
\text { Super phosphate - } 1 \text { T/acre }\end{array}$ & 104 & 86.66 & 16 & 13.33 \\
\hline 7 & $\begin{array}{l}\text { Quantities of FYM } \\
16 \text { T/acre }\end{array}$ & 100 & 83.33 & 20 & 16.66 \\
\hline 8 & $\begin{array}{l}\text { Chemical fertilizers } \\
\text { N P K }\end{array}$ & & & & \\
\hline 9 & $\begin{array}{l}\text { Summer - } 40+40+60 \mathrm{Kg} / \mathrm{acre} \\
\text { Winter }-30+50+50 \mathrm{Kg} / \mathrm{acre}\end{array}$ & $\begin{array}{l}32 \\
36\end{array}$ & $\begin{array}{c}26.66 \\
30\end{array}$ & $\begin{array}{l}88 \\
84\end{array}$ & $\begin{array}{c}73.33 \\
70\end{array}$ \\
\hline 10 & $\begin{array}{l}\text { Recommended rootstocks } \\
\text { Dog ridge, Salt creek, Freedom }\end{array}$ & 120 & 100 & 0 & 0 \\
\hline 11 & $\begin{array}{l}\text { Method of rootstock grafting } \\
\text { Wedge grafting }\end{array}$ & 40 & 33.33 & 80 & 66.66 \\
\hline 12 & $\begin{array}{l}\text { Time for rootstock grafting } \\
\text { September - October }\end{array}$ & 84 & 70 & 36 & 30 \\
\hline 13 & $\begin{array}{l}\text { Recommended training methods } \\
\text { Y system }\end{array}$ & 120 & 100 & 0 & 0 \\
\hline 14 & $\begin{array}{l}\text { Irrigation method } \\
\text { Drip irrigation }\end{array}$ & 120 & 100 & 0 & 0 \\
\hline
\end{tabular}




\begin{tabular}{|c|c|c|c|c|c|}
\hline 15 & Pruning time (B\&F) & 116 & 96.66 & 4 & 3.33 \\
\hline & April and September & & & & \\
\hline 16 & Buds at summer pruning & 112 & 93.33 & 8 & 6.66 \\
\hline 17 & Buds at winter pruning & 92 & 76.66 & 28 & 23.33 \\
\hline 18 & i. Cycocyl application(retardants) & 64 & 53.33 & 56 & 46.66 \\
\hline & 5 leaf Stage (after winter pruning) & & & & \\
\hline 19 & ii. Conc.500 ppm & 68 & 56.66 & 52 & 43.33 \\
\hline 20 & Growth regulators & 116 & 96.66 & 4 & 3.33 \\
\hline & i. GA application Stage & & & & \\
\hline & $\begin{array}{l}\text { Pre-bloom stage } \\
\text { (after winter pruning) }\end{array}$ & & & & \\
\hline 21 & ii. Conc. 10 ppm & 116 & 96.66 & 4 & 3.33 \\
\hline 22 & Major pests & 92 & 76.66 & 28 & 23.33 \\
\hline 23 & Major diseases & 96 & 80 & 24 & 20 \\
\hline 24 & Pest control & & & & \\
\hline & a. Thrips & 120 & 100 & 0 & 0 \\
\hline & b. Flea beetle & 104 & 86.66 & 16 & 13.33 \\
\hline & c. Mealy bugs & 60 & 50 & 60 & 50 \\
\hline 25 & Disease control & 108 & 90 & 12 & 10 \\
\hline & a. $\quad$ Powdery mildew & 120 & 100 & 0 & 0 \\
\hline & b. $\quad$ Downey mildew & 120 & 100 & 0 & 0 \\
\hline 26 & c. Anthracnose & & & & \\
\hline & Marketing & 56 & 46.66 & 64 & 53.33 \\
\hline
\end{tabular}

Table.2 Overall knowledge level of the Thompson seedless grape growers about recommended practices of grape cultivation

\begin{tabular}{|l|c|c|c|c|}
\hline \multirow{2}{*}{$\begin{array}{c}\text { Knowledge } \\
\text { categories }\end{array}$} & \multicolumn{2}{|c|}{$\begin{array}{c}(\mathrm{n}=120) \\
\text { Criteria }\end{array}$} & Respondents & $\begin{array}{c}\text { Mean } \\
\text { knowledge } \\
\text { score }\end{array}$ \\
\hline Low & Less than 18.59 & 20 & 16.67 & 18.14 \\
\hline Medium & Between 18.59-23.81 & 25 & 20.83 & 19.16 \\
\hline High & More than 23.81 & 75 & 62.50 & 20.16 \\
\hline
\end{tabular}

Mean $=24.16 ;$ S. D. $=3.14$ 
Table.3 Adoption of grape cultivation practices by the Thompson seedless grape growers

\begin{tabular}{|c|c|c|c|c|c|}
\hline \multirow{2}{*}{$\begin{array}{l}\text { Sl. } \\
\text { No. }\end{array}$} & \multirow[t]{2}{*}{ Cultivation practices } & \multicolumn{2}{|c|}{ Adoption level } & \multicolumn{2}{|c|}{ Non Adoption level } \\
\hline & & No & $\%$ & No & $\%$ \\
\hline 1 & $\begin{array}{l}\text { Soil type } \\
\text { Well drained sandy loam }\end{array}$ & 120 & 100 & 0 & 0 \\
\hline 2 & $\begin{array}{l}\text { Varieties grown } \\
\text { Thompson seedless }\end{array}$ & 120 & 100 & 0 & 0 \\
\hline 3 & $\begin{array}{l}\text { Spacing followed } \\
3 \mathrm{~m} \mathrm{X} 3 \mathrm{~m}\end{array}$ & 104 & 86.66 & 16 & 13.33 \\
\hline 4 & $\begin{array}{l}\text { Trench/pit size prepared } \\
1-2 \mathrm{cu} . \mathrm{ft}\end{array}$ & 120 & 100 & 0 & 0 \\
\hline 5 & $\begin{array}{l}\text { Rootstock adopted } \\
\text { Dog ridge }\end{array}$ & 120 & 100 & 0 & 0 \\
\hline 6 & $\begin{array}{l}\text { Rootstock grafting method adopted } \\
\text { Wedge }\end{array}$ & 40 & 33.33 & 80 & 66.67 \\
\hline 7 & $\begin{array}{l}\text { Time for rootstock grafting } \\
\text { September - October }\end{array}$ & 120 & 100 & 0 & 0 \\
\hline 8 & $\begin{array}{l}\text { Training method adopted* } \\
\text { Y method of training }\end{array}$ & 120 & 100 & 0 & 0 \\
\hline 9 & $\begin{array}{l}\text { Irrigation method } \\
\text { Drip irrigation }\end{array}$ & 120 & 100 & 0 & 0 \\
\hline 10 & $\begin{array}{l}\text { Pruning time followed } \\
\text { i. Summer pruning } \\
\text { April } \\
\text { ii.Winter pruning } \\
\text { October }\end{array}$ & $\begin{array}{l}120 \\
120\end{array}$ & $\begin{array}{l}100 \\
100\end{array}$ & $\begin{array}{l}0 \\
0\end{array}$ & $\begin{array}{l}0 \\
0\end{array}$ \\
\hline 11 & Buds retrained at summer pruning & 112 & 93.33 & 8 & 6.67 \\
\hline 12 & Buds retrained at winter pruning & 92 & 76.66 & 28 & 23.33 \\
\hline
\end{tabular}

Table.3(a) Adoption of grape cultivation practices by the Thompson seedless grape growers

\begin{tabular}{|c|c|c|c|c|c|}
\hline \multirow{2}{*}{$\begin{array}{l}\text { Sl. } \\
\text { No. }\end{array}$} & \multirow[t]{2}{*}{ Cultivation practices } & \multicolumn{2}{|c|}{ Adoption level } & \multicolumn{2}{|c|}{ Non adoption } \\
\hline & & No & $\%$ & No & $\%$ \\
\hline \multirow[t]{2}{*}{1} & Pit opening season & 120 & 100 & 0 & 0 \\
\hline & Soaking irrigation for pit & 120 & 100 & 0 & 0 \\
\hline \multirow[t]{3}{*}{2} & Propagation through stem cutting & 108 & 90 & 12 & 10 \\
\hline & Retained buds on stem cutting & 108 & 90 & 12 & 10 \\
\hline & Selection cutting for pruning & 120 & 100 & 0 & 0 \\
\hline \multirow[t]{3}{*}{3} & Planting age of cutting & 108 & 90 & 12 & 10 \\
\hline & Month of planting & 84 & 70 & 36 & 30 \\
\hline & Staking of grape & 120 & 100 & 0 & 0 \\
\hline 4 & Skilled labour for training & 104 & 86.66 & 16 & 13.34 \\
\hline \multirow[t]{3}{*}{5} & Back prune tertiary branches & 108 & 90 & 12 & 10 \\
\hline & Forward prune tertiary branch & 108 & 90 & 12 & 10 \\
\hline & Sub cane at summer prune & 112 & 93.33 & 8 & 6.67 \\
\hline$\overline{6}$ & Harvest & 116 & 96.66 & 4 & 3.34 \\
\hline
\end{tabular}


Table.4 Overall adoption level of recommended practices of Thompson seedless grape growers

\begin{tabular}{|c|c|c|c|c|}
\hline \multirow{2}{*}{$\begin{array}{l}\text { Adoption } \\
\text { categories }\end{array}$} & \multirow[b]{2}{*}{ Criteria } & \multicolumn{2}{|c|}{ Respondents } & \multirow{2}{*}{$\begin{array}{c}\text { Mean } \\
\text { adoption } \\
\text { score }\end{array}$} \\
\hline & & Frequency & Percentage & \\
\hline Low & Less than 30.54 & 8 & 6.67 & 30.15 \\
\hline Medium & Between 30.54-34.18 & 8 & 6.67 & 31.35 \\
\hline High & More than 34.18 & 104 & 86.66 & 32.36 \\
\hline & Total & 120 & 100 & \\
\hline
\end{tabular}

Mean $=34.36 ;$ S. D. $=3.63$

$\mathrm{Y}$ methods is most preferred and widely adopted system, because training is a unique practice in grape cultivation which enables viticulturist to maintain the stature and spread of the vine and it will be convenient to carry out the operations like pruning, inter culture, spraying and harvesting. Though the study area received considerable amount of rainfall, prevalence of dry spell was observed to be quite often in this area. So, more emphasis is given to conserve the available water and hence farmers are willing to take up water saving measures to irrigate the orchard. To overcome this, government is providing subsidy for drip irrigation. In addition to this, drip irrigation helps to reduce salinity hazards and also helps to integrate fertigation practices. Cent per cent of respondents had adopted pruning operation at the right time. It is done to concentrate the growth activity of the vine in the parts left after pruning and to induce sprouting of the fruitful buds located in the middle portion of the canes.

The results presented in Table 3(a) revealed that, cent per cent of respondents had adopted cultivation practices like pit opening season, soaking irrigation for the pit and staking operation for grape. As high as 90 per cent of respondents had adopted cultivation practices like propagation through cutting, retention of buds on stem cutting, planting age of cutting, both back and forward prune of tertiary braches and maintenance of sub canes at summer pruning. Around 96.66 per cent of grape growers were adopted harvesting practices of bunches during morning hour and rest of them were at evening hours. The possible reason for adoption of these practices was simple and low cost practices. They were also aware that, to raise a healthy grape garden, staking to grape vines is one of the important low cost technologies where in it provides a support to grape vines to establish them on training structure properly. As high as 90 per cent of respondents had adopted cultivation practices like propagation through cutting, retention of buds on stem cutting, planting age of cutting, both back and forward prune of tertiary braches and maintenance of sub canes at summer pruning. The possible reason might be it can be used for goat and cattle feed in off season. Most $(96.66 \%)$ of grape growers adopted harvesting practices of bunches during morning hour and rest of were at evening hours. The advantage of harvesting of bunches during morning hours is that fetches more price due to its freshness and availability of labours is high when compared to evening hours.

The results presented in Table 4 revealed that only 6.67 per cent of the grape growers belonged to low and medium adoption category with mean adoption score of 34.36 and 86.66 per cent of grape growers belonged to high adoption categories. Knowledge of the individual as it is the basic for any individual to think of pros and cons in making a decision to adopt or reject a practice, hence reason for 
more number of the grape growers to fall under high adoption category was high knowledge possessed by majority of the respondents. Similar findings were reported by Sainath (1982) and Siddaraju (1992) and Govindagowda (2002) and Gotyal (2007) on grape crops in Bangalore district.

\section{References}

APEDA, 2012. Manual for Export of Grapes, APEDA, New Delhi, Pp. 31-35.

Gotyal, S. H., 2007. Backward and forward linkages of grape production in Karnataka. Ph.D. Thesis (Unpub.), Univ. Agric. Sci., Dharwad.

Govinda Gowda, V., 2002. Adoption analysis of sustainable grape cultivation practices adopted by Bangalore Blue and Thompson Seedless growers in Bijapur and Bangalore rural districts in Karnataka. Ph.D. Thesis, (Unpub.)Univ. Agric. Sci., Bangalore.

Sainath, S., 1982. A study on adoption behaviour and motivational pattern of grape cultivation in Bangalore district of Karnataka. M.Sc. (Agri) Thesis (Unpub.) Univ. Agril. Sci. Bangalore.

Siddaraju, G. C., 1992. Impact analysis of Grape Development Scheme on beneficiaries and non-beneficiaries with respect to their knowledge and adoption of improved farm technology. M.Sc. (Agri.) Thesis, (Unpub.)Univ. Agric. Sci., Bangalore.

\section{How to cite this article:}

Dasharath Dodamani, G.R. Pennobaliswamy, S. Mahantesh and Gajanand, P. 2018. Knowledge and Adoption Level of Thompson Seedless Grape Growers of Bijapur District of Karnataka, India. Int.J.Curr.Microbiol.App.Sci. 7(01): 2202-2209.

doi: https://doi.org/10.20546/ijcmas.2018.701.265 